\title{
DNA Repair Protein RAD50
}

National Cancer Institute

\section{Source}

National Cancer Institute. DNA Repair Protein RAD50. NCI Thesaurus. Code C104710.

DNA repair protein RAD50 (1312 aa, $154 \mathrm{kDa}$ ) is encoded by the human RAD50 gene.

This protein plays a role in DNA double-strand break repair, cell cycle checkpoint activation, telomere maintenance, and meiotic recombination. 